\title{
Is glucagon-like peptide 1 an incretin hormone?
}

\author{
Michael A. Nauck \\ Department of Medicine, Knappschafts-Krankenhaus, Ruhr-University Bochum, Germany
}

Summary Glucagon-like peptide-1 (GLP-1) was predicted, based on the proglucagon gene sequence. It is synthesised by specific post-translational processing in $\mathrm{L}$ cells (lower intestine) and secreted mainly as "truncated" GLP-1 [7-36 amide] in response to nutrient ingestion. Glucagon-like peptide-1 stimulates insulin secretion during hyperglycaemia, suppresses glucagon secretion, stimulates (pro)insulin biosynthesis and decelerates gastric emptying and acid secretion. On intracerebroventricular injection, GLP-1 reduces food intake in rodents. A GLP-1 receptor antagonist or GLP-1 antisera have been shown to reduce meal-stimulated insulin secretion in animals, suggesting that GLP-1 has a physiological "incretin" function (augmentation of postprandial insulin secretion due to intestinal hormones) for GLP-1. In healthy human subjects, exogenous GLP-1 slows gastric emptying. Consequently, postprandial insulin secretion is reduced, not augmented. Thus, a participation of this peptide in the incretin effect of non-diabetic humans has not been definitely proven. Nevertheless, it has potent insulinotropic activity, especially during hyperglycaemia. This suggests new therapeutic options for patients with Type II (non-insulin-dependent) diabetes mellitus. On the other hand, most L cells are located in the lower small intestine. Potent inhibitory actions of GLP-1 on upper gastrointestinal motor and digestive functions (e.g. gastric emptying and acid secretion) in response to nutrients placed into the ileal lumen, argue for a role of this peptide as an "ileal brake". Malassimilation and diarrhea leading to the erroneous presence of nutrients in the lower gut may, via GLP-1, delay gastric emptying and reduce upper gut motility and thereby prevent further caloric losses. [Diabetologia (1999) 42: 373379]

Keywords Glucagon-like peptide 1, incretin hormones, ileal brake, insulin, glucagon, motility, gastric emptying
Discovery of GLP-1. Glucagon-like peptide 1 (GLP1) was predicted after its nucleotide sequence was noticed during sequence analysis of the preproglucagon gene [1]. This precursor protein contains the sequence of pancreatic glucagon and has two additional nucleotide stretches. If translated into the amino acid sequence, these are similar to glucagon (approxi-

Received: 4 August 1998 and in revised form: 8 October 1998

Corresponding author: Professor M. Nauck, Medizinische Universitätsklinik, Knappschafts-Krankenhaus, In der Schornau 23-25, D-44892 Bochum, Germany

Abbreviations: GLP-1, Glugagon-like peptide 1; GIP, glucosedependent insulin-releasing peptide mately 50\% homology) and therefore named GLP-1 and GLP-2. Speculations about physiological functions were mainly based on sequence homology to other members of the glucagon-secretin family of gastrointestinal peptide hormones. Therefore, GLP1 and GLP-2 were first tested for insulinotropic activity [2]. But additional effects of GLP-1 have been discovered and it is not decided what the physiological function of GLP-1 in healthy animals and humans could be.

Incretin hormones. The definition of the incretin effect and incretin hormones by Creutzfeldt [3] has been widely accepted and used: the incretin effect describes the phenomenon of oral glucose eliciting a 
greater insulin response than intravenous glucose infusions, no matter whether the same amount of glucose is infused [4] or an equivalent rise in glycaemia is caused by the parenteral route [5]. These experiments showed that up to $60 \%$ of the insulin secretory response after an oral glucose load are not caused by a direct interaction of glucose with beta cells in the islets of Langerhans, but by the secretion and insulinotropic action of gut peptides [5]. Incretin hormones are gut factors released by oral nutrients, which stimulate insulin secretion at the typical postprandial concentrations reached in the presence of hyperglycaemia [3]. As an intravenous infusion of glucose-dependent insulin-releasing peptide (GIP) and glucose, which leads to similar concentrations of glucose and GIP as an oral glucose load, augments insulin secretion to the same extent [6-8], GIP was identified as the first incretin candidate [3,9]. Based on the insulinotropic activity of intestinal mucosal extracts which had been depleted of GIP [10], and on a continuing incretin effect when circulating GIP was inactivated by anti-GIP antibodies [11], additional incretin hormones were, however, postulated. Then GLP-1 was discovered. This peptide was found to be insulinotropic, i.e. to stimulate insulin secretion, especially at raised glucose concentrations [2]. It had been predicted [2] and later shown that this ability was much more pronounced in the case of "truncated" GLP-1 (GLP-1 [7-36 amide]) [12,13]. Therefore, it was suggested that GLP-1 is an incretin hormone $[7,8]$ contributing to meal-stimulated insulin secretory responses.

Synthesis, processing and secretion of GLP-1, receptor and signal transduction. For basic information on the biology of GLP-1, readers are referred to several excellent reviews [14-16]. The proglucagon gene is expressed in alpha cells of the islets of Langerhans and in L cells of the gut. These are endocrine cells present in large numbers in the ileum and colon and in much smaller numbers in the duodenum and jejunum [17]. Whereas the main product of post-translational processing of proglucagon in the endocrine pancreas is glucagon, in L cells glicentin ("enteroglucagon"), GLP-1 and GLP-2 are the main final products. Differential processing is thought to be due to different prohormone convertases. The final form of GLP-1 that is produced in L cells is "truncated" GLP-1 [12]. It occurs mainly in the C-terminally amidated form (GLP-1 [7-36 amide]). A minor product is the glycine-extended (i.e. non-amidated) GLP-1 [7-37] [18]. The term "truncation" refers to the originally proposed sequences GLP-1 [1-36 amide] (or [1-37]), which does not occur as such in larger quantities [14].

Glucagon-like peptide-1 is secreted from isolated perfused ileum preparations $[19,20]$ when glucose or fat are infused through the gut lumen. Nutrients in- fused directly into the ileal lumen release GLP-1 [21], indicating that direct stimulation of L-cell secretion is possible in humans. Oral glucose [7, 8, 22-24], sucrose [25], triglycerides [22] and mixed meals also lead to an increment in plasma GLP-1 [14-16]. These nutrient-related GLP-1 responses start early (i.e. within $5 \mathrm{~min}$ ) after ingestion [8], and last for approximately an hour $[8,22,26]$. It is doubtful, that nutrients have reached portions of the gut with high L-cell densities by that time. Especially oral glucose is completely absorbed from the duodenum and upper jejunum [27]. Therefore, indirect signalling pathways may exist that stimulate L-cell secretion if glucose is present in the duodenum.

Glucose-dependent insulin-releasing peptide is, however, released from the duodenum and upper jejunum, where K cells are abundant [6]. First GIP increments are seen within 15 min after nutrient ingestion and can last for several hours [28]. Therefore, GIP may qualify for an incretin role especially regarding the later postprandial insulin secretory response.

Glucose-dependent insulin-releasing peptide appears to be an "upper gut signal" for the release of GLP-1 in rodents [29], but not in humans [26].

Lower gut resections (removing the most abundant stores of GLP-1) do not alter GLP-1 responses after oral glucose [23]. Quantitative considerations allow the conclusion that the amount of GLP-1 present in the upper jejunum is still several fold higher than the amount released in response to a single nutrient stimulus [23].

Glucagon-like peptide-1 has a short plasma halflife and is inactivated by dipeptidyl peptidase IV present in blood plasma $[30,31]$. After intravenous infusions with GLP-1, more than $70 \%$ of GLP-1-like material measured with non-specific assays was N-terminally degraded [31].

Binding sites for GLP-1 are present on insulinoma cells [32] and a receptor has been cloned [33, 34]. It belongs to the 7 trans-membrane-domain family of receptors and is expressed in islets of Langerhans (beta cells, delta cells, and possibly alpha cells) [35]. The major second messenger is cAMP [36]. In addition, the activation of other signal transduction pathways leading to increased intracellular $\mathrm{Ca}^{++}$concentrations have also been described [37].

Effects of GLP-1 in normal animals and humans. Insulinotropic effects of GLP-1 have already been mentioned, but this is not the only biological action of GLP-1.

(1) GLP-1 stimulates insulin secretion in isolated islets of Langerhans [2], in the perfused pancreas [12, 13], and in whole organisms, both in animals and humans [7, 8, 38]. Its effects are glucose-dependent, with greater effects occurring at higher glucose con- 
centrations $[7,8,39]$. At normal fasting glucose concentrations only small effects on insulin secretion can be achieved which are not strong enough to cause clinically manifest hypoglycaemia [39].

(2) GLP-1 is able to suppress glucagon secretion in islets [40], the perfused pancreas [41], and in whole organisms [7]. Recent studies indicate that even basal GLP-1 levels exert a tonic inhibitory effect on glucagon secretion [42].

(3) In insulinoma cell lines, GLP-1 is able to promote (pro)insulin biosynthesis [43], which could be important for maintaining insulin stores when secretion tends to deplete them.

(4) GLP-1 decelerates gastric emptying in normal subjects $[44,45]$ as well as in Type II diabetic patients [46]. Effects are found at physiological doses (plasma concentrations $\sim 25 \mathrm{pmol} / \mathrm{l}$ ) [45]. GLP-1 has been shown to reduce pancreatic enzyme output (exocrine secretion), probably due to retarded gastric emptying, [44]. It may also change the small intestinal motility pattern.

(5) Gastric acid secretion is reduced by $30-50 \%$ in healthy human volunteers receiving intravenous infusions of GLP-1 [47]. Since vagotomy abolishes this effect [48], it is probably mediated by vagal fibres.

(6) GLP-1 in microgram amounts injected into the cerebrospinal fluid of rodents reduces food intake [49]. A specific antagonist at the GLP-1 receptor, exendin [9-39], enhances food intake in mice [49]. Since GLP-1 [7-36 amide] is synthesised in certain brain nuclei, a physiological, inhibitory effect on food intake involving cerebral GLP-1 receptors in the hypothalamus has been suggested. In healthy volunteers receiving an intravenous infusion of GLP-1, satiety was rated higher than with placebo and caloric intake during a second meal was considerably reduced [50]. These results point to a function for GLP-1 in the regulation of food intake.

(7) Minor effects of GLP-1 on insulin sensitivity have been described [51, 52], but questioned. Recent data indicate that metabolic actions of GLP-1 can only be expected under circumstances that allow changes in glucoregulatory hormones (insulin and glucagon). The quantitative importance of so-called "extrapancreatic or peripheral effects" is negligible $[53,54]$.

\section{Physiological roles of GLP-1}

Animal studies. The GLP-1 receptor antagonist exendin [9-39] [34, 55] has been used to study the importance of endogenous GLP-1 release for postprandial insulin secretion, i.e. an incretin role for GLP-1. Exendin [9-39] specifically inhibits GLP-1-induced insulin secretion but leaves the effect of other insulin secretagogues unaffected [56]. In rats, exendin [9-39] reduces insulin secretory responses to intraduodenal glucose [38] and to the oral intake of nu- trients [56]. This is of interest because in the first case potential effects on gastric emptying should not be of any importance, whereas in the second, deceleration of gastric emptying due to GLP-1 might occur. An explicit measurement of gastric emptying, however, has not been taken under these study conditions.

In mice lacking a functional GLP-1 receptor (homozygous GLP-1 receptor "knockout"), a considerably reduced insulin response after oral glucose and oral as well as (less pronounced) intraperitoneal glucose intolerance has been described [57]. Fasting hyperglycaemia was only seen in male animals. Body weight was normal. Short-term responses to intracerebroventricular GLP-1 were, however, predictably missing in receptor "knock-out" mice, but could be shown in control animals.

In baboons, treatment with exendin [9-39] or specific anti-GLP-1 antibodies delayed initial insulin responses after the oral ingestion of glucose. Later, glucose increased to higher concentrations [58]. D-xylose absorption kinetics were similar with and without GLP-1 receptor antagonist/antibody treatment. Therefore, a major (confounding) effect on gastric emptying appears improbable. As far as can be ascertained from these experiments, GLP-1 is a weak physiological incretin hormone also in baboons, with most of its effect occurring in the initial postprandial phase.

Studies in non-diabetic humans. In healthy human subjects, an incretin activity of GLP-1 has been concluded from its influence on insulin secretory responses during combined treatment with glucose and GLP-1 [7, 8]. In such experiments, plasma GLP-1 concentrations after oral glucose have to be closely matched by intravenous infusions. It has been concluded from experiments using slightly supraphysiological GLP-1 concentrations, that GLP-1 is a physiological incretin in man [7]. Our studies, using a strictly physiological glucose increment (matched to the rise in glycaemia after oral glucose) confirmed the augmentation of insulin secretion by GLP-1. The estimated contribution to the overall incretin effect, however, was small (approximately $25 \%$ ) [8]. These experimental approaches did not take into account gastric motility which indirectly influences meal-induced insulin secretory responses [45].

Exogenous treatment with physiological and pharmacological doses of GLP-1 together with an intragastric liquid meal resulted in a dose-dependent slowing of gastric emptying [45]. While there was a dosedependent increment in fasting insulin (GLP-1 was started $30 \mathrm{~min}$ prior to the meal), insulin secretion after nutrient ingestion was either not changed (low dose of GLP-1) or even depressed (higher doses of GLP-1; Fig.1, left panels). Inhibitory effects on gastric emptying and the subsequent reduction in sub- 

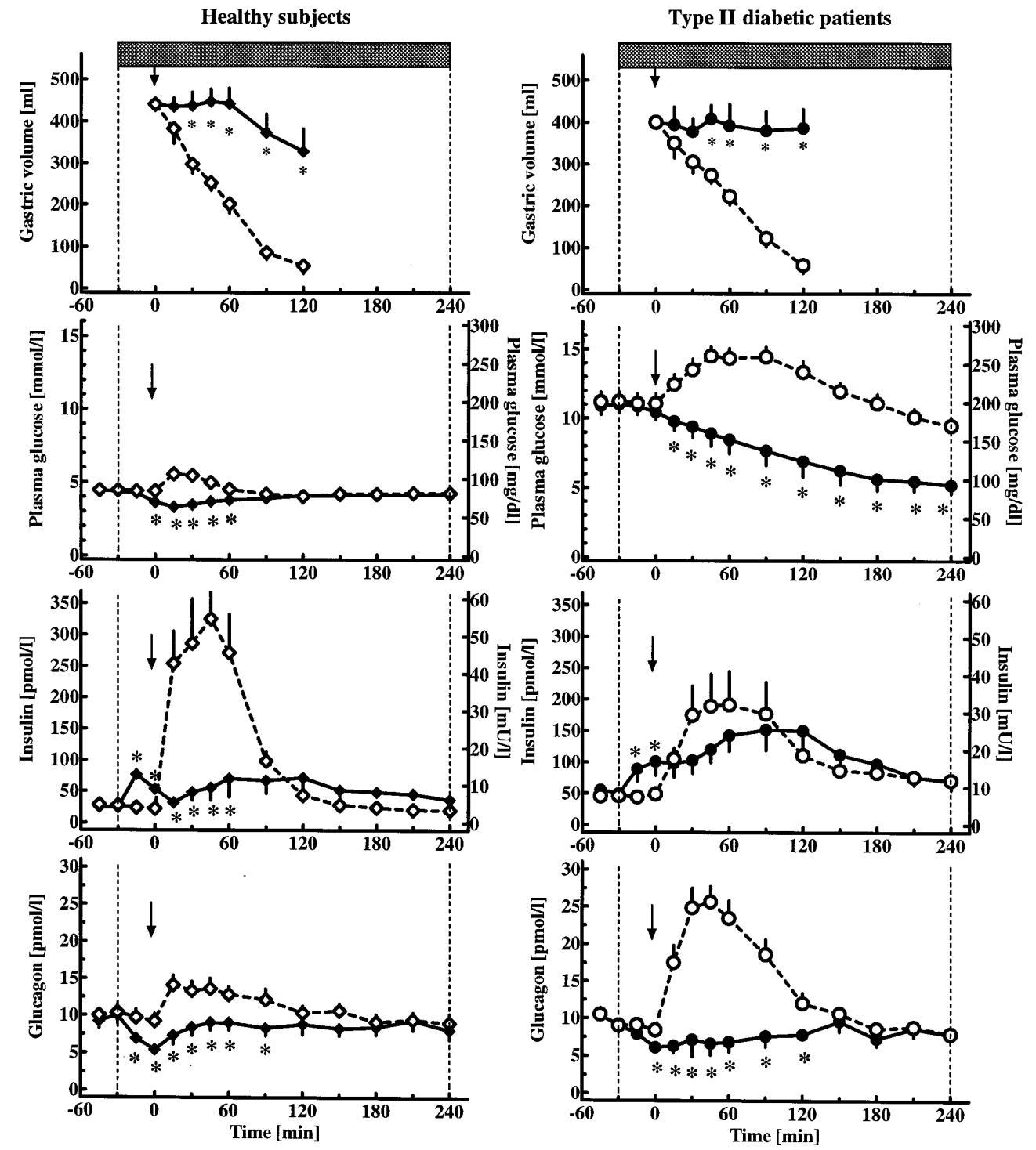

Fig. 1. Gastric volume (upper panels), plasma glucose concentrations (second row of panels), plasma insulin responses (third row of panels), and glucagon concentrations (lower panels) in response to the intravenous infusion of GLP-1 (1.2 $\mathrm{pmol} \cdot \mathrm{kg}^{-1} \cdot \mathrm{min}^{-1}$ ) or placebo (duration indicated by the bars) starting 30 min before a liquid meal was transported intragastrically into healthy volunteers (left panels) or Type II diabetic patients (right panels). Open symbols: placebo; closed symbols: GLP-1. Mean \pm SEM. Repeated-measures analysis of variance indicated $p$-values $<0.01$ for the interaction of experiment (GLP-1 vs placebo) and time for all comparisons made. Asterisks indicate significant differences at individual time points. Redrawn with modifications from Nauck et al. [45] and Willms et al. [46]

strate-stimulated insulin secretion, therefore, outweighed the small direct (stimulatory) effects on beta cells. Insulinotropic effects of GLP-1 are probably limited by the lack of appropriate hyperglycaemia under these conditions [39]. These findings question a physiological incretin role for GLP-1 in healthy (nondiabetic) human subjects. Additional information is

expected from the use of exendin [9-39], which has been tested as a GLP-1 receptor antagonist also in humans $[42,67]$.

Possible differences in the relative importance of incretin hormones between animals and humans. The contribution of incretin hormones to postprandial insulin secretion appears to be similar in rats [38] and healthy human subjects [5]: more than $50 \%$ are contributed by insulinotropic gut hormones. Peptide antagonists of GLP-1 (exendin [9-39]) [38] and of GIP [59] considerably reduce postprandial insulin responses after oral, intragastric or intraduodenal glucose loads. Since GIP releases GLP-1 in rats (and other rodents) [20, 29], antagonising GIP actions should also partly take away the GLP-1 response. Based on a similar glucose-concentration dependence of their insulinotropic activities, but higher plasma concentrations of GIP both in the basal and postprandial state, it has been concluded that GIP is probably the quantitatively more important incretin 
hormone in rodents [60]. In human subjects, GIP does not change GLP-1 secretion even at pharmacological levels [26].

Insulinotropic actions of GLP-1 in Type II diabetic patients. In contrast to GIP [26, 61], GLP-1 has a well preserved insulinotropic [26] and glucagonostatic [26, 62] activity in Type II diabetic patients. Furthermore, deceleration of gastric emptying is observed in Type II diabetic patients and in healthy subjects (Fig. 1; [46]).

Since the insulinotropic actions of GLP-1 depend on increased glucose concentrations [39], the fasting hyperglycaemia of Type II diabetic patients permits augmentation of postprandial insulin responses despite retardation of gastric emptying and delayed nutrient absorption (Fig. 1, right panels [46]). The result is a reduction in glucose concentrations even with nutrients present in the stomach. This is based on (a) a reduced nutrient inflow and (b) a rise in insulin concentrations. The increment in insulinaemia is similar to placebo conditions, when gastric emptying proceeds at its normal rate and insulinotropic substrates like glucose are absorbed. Even in the absence of nutrient stimulation, insulin secretion is augmented to a similar degree by the combined action of hyperglycaemia and GLP-1. This is in contrast to healthy subjects (Fig.1, left panels [45]), in whom only minor effects of exogenous GLP-1 on postprandial glycaemic excursions were seen, probably because slowed gastric emptying leads to reduced substrate-stimulated insulin secretion. A lack of hyperglycaemia precludes prominent insulinotropic effects of GLP-1. The result is a net inhibition of insulin secretory responses by GLP-1 except for a short initial insulin response after starting GLP-1 infusions at euglycaemia (Fig. 1).

Glucagon-like peptide-1 as a pharmacological agent appears to have a definite therapeutic potential in Type II diabetic patients $[51,62,63]$. The responsible mechanisms need not necessarily be a copy of its physiological functions. The glucose-lowering activity of GLP-1 in Type II diabetic patients appears to be the consequence of insulinotropic actions during hyperglycaemia [26, 62], a suppression of glucagon secretion [26, 62], and decelerated gastric emptying $[46,51]$ (e.g. Fig. 1, right panels).

Pathophysiology of abnormal GLP-1 secretion. Intestinal resections at the level of the jejunum, ileum or colon do not reduce the GLP-1 secretory response after oral glucose [23]. Nutrient-induced GLP-1 secretion can be augmented by $\alpha$-glucosidase inhibition $[25,64,65]$. Acarbose or voglibose, under these conditions, induce maldigestion of disaccharides, and move intestinal contents downward. Delayed absorption takes place in GLP-1-rich intestinal segments (e.g. the ileum). Nutrients infused directly into the ileum also release GLP-1 [21].
Malassimilation (diarrhea) due to other causes has been shown to augment the secretion of enteroglucagon [66]. Since GLP-1 and enteroglucagon (glicentin) are co-secreted, GLP-1 responses can be predicted to be more prominent under conditions of incomplete absorption of nutrients, for instance in the case of rapid small intestinal transit.

GLP-1 participation in "ileal brake" mechanisms. Under such abnormal circumstances, a signal from the lower gut (e.g. GLP-1) that (a) stops or retards gastric emptying and (b) slows digestive functions (gastric acid and pancreatic juice secretion) would limit nutritional losses. The secretion of GLP-1 in response to nutrients transported into the ileum is accompanied by inhibitory actions on the upper digestive tract [21]. Participation in such "ileal brake" mechanisms are probably a predominant function of GLP-1. In this context, the location of L cells in the lower gastrointestinal tract is much more plausible than in connection with a potential incretin role.

Conclusion. Glucagon-like peptide- 1 is a multifunctional peptide hormone from the lower gut. Among the many possible functions reported, a physiological incretin role in healthy human subjects is unproven and is possibly of minor physiological importance. This peptide may function as a safeguard against intestinal nutrient overload in case of carbohydrate or fat malassimilation, i.e. as a mediator of "ileal brake" mechanisms. Only in the presence of hyperglycaemia, such as in Type II diabetes, are insulinotropic actions of GLP-1 prominent enough to provide a rationale for new therapeutic strategies.

Acknowledgements. Dr. C. Creutzfeldt and Professor W. Creutzfeldt have made helpful suggestions. The secretarial help of $\mathrm{H}$. Achner is greatly acknowledged.

\section{References}

1. Bell GI, Sanchez-Pescador R, Laybourn PJ, Najarian RC (1983) Exon duplication and divergence in the human preproglucagon gene. Nature 304: 368-371

2. Schmidt WE, Siegel EG, Creutzfeldt W (1985) Glucagonlike peptide 1 but not glucagon-like peptide 2 stimulates insulin release from isolated rat pancreatic islets. Diabetologia 28: 704-707

3. Creutzfeldt W (1979) The incretin concept today. Diabetologia 16: 75-85

4. Tillil H, Shapiro ET, Miller A et al. (1988) Dose-dependent effects of oral and intravenous glucose on insulin secretion and clearance in normal humans. Am J Physiol (Endocrinol Metab) 254: E349-E357

5. Nauck MA, Homberger E, Siegel EG et al. (1986) Incretin effects of increasing glucose loads in man calculated from venous insulin and C-peptide responses. J Clin Endocrinol Metab 63: 492-498

6. Brown JC (1982) Gastric inhibitory polypeptide. Monographs in Endocrinology, vol 24. Springer Verlag, Berlin Heidelberg New York 
7. Kreymann B, Williams G, Ghatei MA, Bloom SR (1987) Glucagon-like peptide-1 [7-36]: a physiological incretin in man. Lancet II: 1300-1304

8. Nauck MA, Bartels E, Ørskov C, Ebert R, Creutzfeldt W (1993) Additive insulinotropic effects of exogenous synthetic human gastric inhibitory polypeptide and glucagonlike peptide-1-(7-36) amide infused at near-physiological insulinotropic hormone and glucose concentrations. J Clin Endocrinol Metab 76: 912-917

9. Creutzfeldt W, Nauck M (1992) Gut hormones and diabetes mellitus. Diabetes Metab Rev 8: 149-177

10. Ebert R, Creutzfeldt W (1982) Influence of gastric inhibitory polypeptide antiserum on glucose-induced insulin secretion in rats. Endocrinology 111: 1601-1606

11. Ebert R, Unger H, Creutzfeldt W (1983) Preservation of incretin activity after removal of gastric inhibitory polypeptide (GIP) from rat gut extracts by immunoadsorption. Diabetologia 24: 449-454

12. Holst JJ, Orskov C, Vagn-Nielsen O, Schwartz TW (1987) Truncated glucagon-like peptide 1, an insulin-releasing hormone from the distal gut. FEBS Lett 211: 169-174

13. Mojsov S, Weir GC, Habener JF (1987) Insulinotropin: glucagon-like peptide I (7-37) co-encoded in the glucagon gene is a potent stimulator of insulin release in the perfused rat pancreas. J Clin Invest 79: 616-619

14. Holst JJ (1994) Glucagonlike peptide 1: a newly discoveredgastrointestinal hormone. Gastroenterology 107: 1848-1855

15. Fehmann HC, Göke R, Göke B (1995) Cell and molecular biology of the incretin hormones glucagon-like peptide-I and glucose-dependent insulin releasing polypeptide. Endocrinol Rev 16: 390-410

16. Nauck MA (1997) Glucagonlike peptide 1. Curr Opin Endocrinol Diabetes 4: 256-261

17. Eissele R, Göke R, Willemer S et al. (1992) Glucagon-like peptide- 1 cells in the gastrointestinal tract and pancreas of rat, pig and man. Eur J Clin Invest 22: 283-291

18. Ørskov C, Rabenhøj L, Wettergren A, Kofod H, Holst JJ (1994) Tissue and plasma concentrations of amidated and glycine-extended glucagon-like peptide 1 in humans. Diabetes 43: 535-539

19. Ørskov C, Knuhtsen S, Baldissera FG, Poulsen SS, Nielsen OV, Holst JJ (1986) Glucagon-like peptides GLP-1 and GLP-2, predicted products of the glucagon gene, are secreted separately from pig small intestine but not pancreas. Endocrinology 119: 1467-1475

20. Herrmann- Rinke C, Vöge A, Hess M, Göke B (1995) Regulation of glucagon-like peptide-1 secretion from rat ileum by neurotransmitters and peptides. J Endocrinol 147: 25-31

21. Layer P, Holst JJ, Grandt D, Goebell H (1995) Ileal release of glucagon-like peptide-1 (GLP-1). Association with inhibition of gastric acid secretion in humans. Dig Dis Sci 40: 1074-1082

22. Herrmann C, Göke R, Richter G, Fehmann HC, Arnold R, Göke B (1995) Glucagon-like peptide-1 and glucose-dependent insulin-releasing polypeptide plasma levels in response to nutrients. Digestion 56: 117-126

23. Nauck MA, Siemsglüß J, Ørskov C, Holst JJ (1996) Release of glucagon-like peptide 1 (GLP-1 [7-36 amide]), gastric inhibitory polypeptide (GIP) and insulin in response to oral glucose after upper and lower intestinal resections. $\mathrm{Z}$ Gastroenterol 34: 159-166

24. Schirra J, Katschinski M, Weidmann C et al. (1996) Gastric emptying and release of incretin hormones after glucose ingestion in humans. J Clin Invest 97: 92-103

25. Qualmann C, Nauck MA, Holst JJ, Ørskov C, Creutzfeldt W (1995) Glucagon-like peptide 1 (7-36 amide) secretion in response to luminal sucrose from the upper and lower gut. A study using alpha-glucosidase inhibition (acarbose). Scand J Gastroenterol 30: 892-896

26. Nauck MA, Heimesaat MM, Ørskov C, Holst JJ, Ebert R, Creutzfeldt W (1993) Preserved incretin activity of glucagon-like peptide 1 [7-36 amide] but not of synthetic human gastric inhibitory polypeptide in patients with type- 2 diabetes mellitus. J Clin Invest 91: 301-307

27. Gray GM (1970) Carbohydrate digestion and absorption. Gastroenterol 58: 96-107

28. Krarup T (1988) Immunoreactive gastric inhibitory polypeptide. Endocrinol Rev 9: 122-133

29. Brubaker PL (1991) Regulation of intestinal proglucagonderived peptide secretion by intestinal regulatory peptides. Endocrinology 128: 3175-3182

30. Deacon CF, Johnsen AH, Holst JJ (1995) Degradation of glucagon-like peptide-1 by human plasma in vitro yields an $\mathrm{N}$-terminally truncated peptide that is a major endogenous metabolite in vivo. J Clin Endocrinol Metab 80: 952-957

31. Deacon CF, Nauck MA, Toft-Nielsen M, Pridal L, Willms B, Holst JJ (1995) Both subcutaneously and intravenously administered glucagon-like peptide 1 are rapidly degraded from the $\mathrm{NH}_{2}$-terminus in type 2-diabetic patients and in healthy subjects. Diabetes 44: 1126-1131

32. Göke R, Conlon JM (1988) Receptors for glucagon-like peptide-1(7-36) amide on rat insulinoma-derived cells. J Endocrinol 116: 357-362

33. Thorens B (1992) Expression cloning of the pancreatic beta cell receptor for the gluco-incretin hormone glucagon-like peptide 1. Proc Natl Acad Sci USA 89: 8641-8645

34. Thorens B, Porret A, Buhler L, Deng SP, Morel P, Widmann C (1993) Cloning and functional expression of the human islet GLP-1 receptor. Demonstration that exendin4 is an agonist and exendin-(9-39) an antagonist of the receptor. Diabetes 42: 1678-1682

35. Wei Y, Mojsov S (1995) Tissue-specific expression of the human receptor for glucagon-like peptide-I:brain, heart and pancreatic forms have the same deduced amino acid sequences. FEBS Lett 358: 219-224

36. Göke R, Trautmann ME, Haus E et al. (1989) Signal transmission after GLP-1(7-36)amide binding in RINm5F cells. Am J Physiol 257: G397-G401

37. Holz GG, Leech CA, Habener JF (1995) Activation of a cAMP-regulated $\mathrm{Ca}(2+)$-signaling pathway in pancreatic beta-cells by the insulinotropic hormone glucagon-like peptide-1. J Biol Chem 270: 17749-17757

38. Kolligs F, Fehmann HC, Göke R, Göke B (1995) Reduction of the incretin effect in rats by the glucagon-like peptide 1 receptor antagonist exendin (9-39) amide. Diabetes 44: $16-19$

39. Qualmann C, Nauck MA, Holst JJ, Ørskov C, Creutzfeldt W (1995) Insulinotropic actions of intravenous glucagonlike peptide-1 (GLP-1) [7-36 amide] in the fasting state in healthy subjects. Acta Diabetol 32: 13-16

40. Moens K, Heimberg H, Flamez D et al. (1996) Expression and functional activity of glucagon, glucagon-like peptide I, and glucose-dependent insulinotropic peptide receptors in rat pancreatic islet cells. Diabetes 45: 257-261

41. Ørskov C, Holst JJ, Nielsen OV (1988) Effect of truncated glucagon-like peptide-1 [proglucagon-(78-107) amide] on endocrine secretion from pig pancreas, antrum, and nonantral stomach. Endocrinology 123: 2009-2013

42. Schirra J, Sturm K, Leicht P, Arnold R, Göke B, Katschinski M (1998) Exendin (9-39)amide is an antagonist of glucagon-like peptide-1 (7-36)amide in humans. J Clin Invest 101: 1421-1430 
43. Fehmann HC, Gherzi R, Göke B (1995) Regulation of islet hormone gene expression by incretin hormones. Exp Clin Endocrinol Diabetes 103 [Suppl 2]: 56-65

44. Wettergren A, Schjoldager B, Mortensen PE, Myhre J, Christiansen J, Holst JJ (1993) Truncated GLP-1 (proglucagon 78-107-amide) inhibits gastric and pancreatic functions in man. Dig Dis Sci 38: 665-673

45. Nauck MA, Niedereichholz U, Ettler R et al. (1997) Glucagon-like peptide 1 inhibition of gastric emptying outweighs its insulinotropic effects in healthy humans. Am J Physiol 273: E981-E988

46. Willms B, Werner J, Holst JJ, Ørskov C, Creutzfeldt W, Nauck MA (1996) Gastric emptying, glucose responses, and insulin secretion after a liquid test meal: effects of exogenous glucagon-like peptide-1 (GLP-1)-(7-36) amide in type 2 (noninsulin-dependent) diabetic patients. J Clin Endocrinol Metab 81: 327-332

47. Schjoldager BT, Mortensen PE, Christiansen J, Ørskov C, Holst JJ (1989) GLP-1 (glucagon-like peptide 1) and truncated GLP-1, fragments of human proglucagon, inhibit gastric acid secretion in humans. Dig Dis Sci 34: 703-708

48. Wettergren A, Petersen H, Orskov C, Christiansen J, Sheikh SP, Holst JJ (1994) Glucagon-like Peptide-1 7-36 amide and peptide YY from the L-cell of the ileal mucosa are potent inhibitors of vagally induced gastric acid secretion in man. Scand J Gastroenterol 29: 501-505

49. Turton MD, D OS, Gunn I et al. (1996) A role for glucagon-like peptide- 1 in the central regulation of feeding. Nature 379: 69-72

50. Flint A, Raben A, Astrup A, Holst JJ (1998) Glucagon-like peptide-1 promotes satiety and suppresses energy intake in humans. J Clin Invest 101: 515-520

51. Gutniak MK, Holst JJ, Ørskov C, Åhren B, Efendic S (1992) Antidiabetogenic effect of glucagon-like peptide-1 (7-36)amide in normal subjects and patients with diabetes mellitus. N Engl J Med 326: 1316-1322

52. Valverde I, Villanueva Penacarrillo ML (1996) In vitro insulinomimetic effects of GLP-1 in liver, muscle and fat. Acta Physiol Scand 157: 359-360

53. Toft-Nielsen M-B, Madsbad S, Holst JJ (1996) The effect of glucagon-like peptide I (GLP-1) on glucose elimination in healthy subjects depends on the pancreatic glucoregulatory hormones. Diabetes 45: 552-556

54. Ørskov L, Holst J, Moller J et al. (1996) GLP-1 does not acutely affect insulin sensitivity in healthy man. Diabetologia 39: 1227-1232

55. Göke R, Fehmann HC, Linn T et al. (1993) Exendin-4 is a high potency agonist and truncated exendin-(9-39)-amide an antagonist at the glucagon-like peptide 1-(7-36)-amide receptor of insulin-secreting beta-cells. J Biol Chem 268: 19650-19655

56. Wang Z, Wang RM, Owji AA, Smith DM, Ghatei MA, Bloom SR (1995) Glucagon-like peptide-1 is a physiological incretin in rat. J Clin Invest 95: 417-421

57. Scrocchi LA, Brown TJ, MaClusky N et al. (1996) Glucose intolerance but normal satiety in mice with a null mutation in the glucagon-like peptide 1 receptor gene. Nat Med 2: $1254-1258$
58. D' Alessio D, Vogel R, Prigeon R et al. (1996) Elimination of the action of glucagon-like peptide 1 causes an impairment of glucose tolerance after nutrient ingestion by healthy baboons. J Clin Invest: 133-138

59. Tseng C-C, Kieffer TJ, Jarboe LA, Usdin TB, Wolfe MM (1996) Postprandial stimulation of insulin release by glucose-dependent insulinotropic peptide (GIP). Effect of a specific glucose-dependent insulinotropic polypeptide receptor antagonist in the rat. J Clin Invest 98: 2440-2445

60. Jia X, Brown JC, Ma P, Pederson RA, McIntosh CH (1995) Effects of glucose-dependent insulinotropic polypeptide and glucagon-like peptide-I-(7-36) on insulin secretion. Am J Physiol 268: E645-E651

61. Jones IR, Owens DR, Moody AJ, Luzio SD, Morris T, Hayes TM (1987) The effects of glucose-dependent insulinotropic polypeptide infused at physiological concentrations in normal subjects and Type 2 (non-insulin-dependent) diabetic patients on glucose tolerance and B-cell secretion. Diabetologia 30: 707-712

62. Nauck MA, Kleine N, Ørskov C, Holst JJ, Willms B, Creutzfeldt W (1993) Normalization of fasting hyperglycaemia by exogenous glucagon-like peptide 1 (7-36 amide) in type 2 (non-insulin-dependent) diabetic patients. Diabetologia 36: 741-744

63. Nauck MA, Holst JJ, Willms B, Schmiegel W (1997) Glucagon-like peptide 1 (GLP-1) as a new therapeutic approach for Type 2-diabetes. Exp Clin Endocrinol Diabet 105: 187-195

64. Göke B, Fuder H, Wieckhorst G et al. (1995) Voglibose (AO-128) is an efficient alpha-glucosidase inhibitor and mobilizes the endogenous GLP-1 reserve. Digestion 56: 493-501

65. Seifarth C, Bergmann J, Holst JJ, Ritzel R, Schmiegel W, Nauck MA (1998) Prolonged and enhanced secretion of glucagon-like peptide 1 (7-36 amide) after oral sucrose due to alpha-glucosidase inhibition (acarbose) in Type 2 diabetic patients. Diabet Med 15: 485-491

66. Besterman HS, Bloom SR, Sarson DL et al. (1978) Guthormone profile in coeliac disease. Lancet I: 785-788

67. Edwards CMB, Todd JF, Mahmoudi M, Wang Z, Wang RM, Ghatei MA, Bloom SR (1999) Glucagon-like peptide 1 has a physiological role in the control of postprandial glucose in humans. Studies with the antagonist exendin 9-39. Diabetes 48: 86-93

Note added in proof: The physiological role of GLP-1 after an oral glucose load has recently been examined using exendin [9-39] in vivo in human volunteers [67]. The insulinotropic effect of exogenous GLP-1 was totally blunted by the GLP-1 antagonist, and plasma and insulin increments during the first 90 min after oral glucose were enhanced by $35 \%(\mathrm{p}<0.05)$ and $24 \%$ (not significant), respectively. This suggests a main action of GLP-1 on gastric emptying (which appears to be accelerated in the presence of exendin [9-39]) and does not easily support an incretin role for GLP-1. The latter would require a reduction in insulin responses in the presence of the GLP-1 antagonist. 